\title{
Implementasi Algoritma K-Means Clustering dalam Menentukan Blok Tanaman Sawit Paling Produktif
}

\author{
Irfan Maulana Pulungan', Saifullah ${ }^{2}$, M.Fauzan ${ }^{3}$, Agus Perdana Windarto ${ }^{4}$ \\ STIKOM Tunas Bangsa Pematangsiantar, Indonesia \\ Jl. Jendral Sudirman Blok A No 1-3 Pematangsiantar 21127, Indonesia \\ Email : irfanlana3@gmail.com
}

\begin{abstract}
PTP.Nusantara-IV (Persero) especially in the Marjandi Gardens located in Panombean Panei, Simalungun Regency is an Indonesian state-owned enterprise engaged in the plantation sector, one of which is Oil Palm. Among the many oil palm plantation blocks, there are productive and unproductive oil palm plant blocks. Unproductive blocks affect the profits of Marjandi Gardens in the production of Palm Oil. Therefore, it is necessary to conduct research to find out the most productive and unproductive blocks of Oil Palm Plants. This study was conducted in Afdeling III Marjandi Gardens with oil palm planting years 2005 and 2006. The method used was the K-Means Clustering method, the blocks were divided into 2 Clusters namely High Clusters for the most productive blocks and Low Clusters for unproductive blocks. Based on the research that has been done, the results obtained are the number of 14 blocks of the most productive oil palm plants, namely ( $B M, B N, B O, B P, B R, B Y$, $C E, C F, C K, C Y, D E, D F, D G)$ and 26 blocks of plants Oil palm is unproductive, namely ( $B L, B Q$, $B S, B W, B X, B Z, C A, C B, C D, C G, C L, C M, C N, C O, C P, C Q, C R, C S, C W, C X, D A, D B, D C, D D)$. It is expected that the company can develop the most productive oil palm block so that the quality of the oil palm plant blocks is always maintained. As for the unproductive oil palm plant blocks, the company can make repairs to produce a productive block of oil palm in the future.
\end{abstract}

Keywords: Block, Oil Palm, Data Mining, K-Means

Abstrak - PTP. Nusantara-IV (Persero) khususnya pada Kebun Marjandi yang terletak di Panombean Panei, Kabupaten Simalungun adalah badan usaha milik negara Indonesia yang bergerak pada bidang perkebunan, salah satunya adalah Kelapa Sawit. Di antara banyak blok-blok Tanaman Kelapa Sawit, ada blok-blok tanaman Kelapa Sawit yang produktif dan tidak produktif. Blok tidak produktif berpengaruh pada keuntungan Kebun Marjandi dalam produksi Kelapa Sawit. Oleh karena itu, perlu dilakukan penelitian untuk mengetahui blok Tanaman Kelapa Sawit paling produktif dan tidak produktif. Penelitian ini dilakukan di Afdeling III Kebun Marjandi dengan tahun tanam Kelapa Sawit 2005 dan 2006. Metode yang digunakan adalah metode Clustering K-Means, blok dibagi menjadi 2 Cluster yaitu Cluster Tinggi untuk blok paling produktif dan Cluster Rendah untuk blok tidak produktif. Berdasarkan penelitian yang telah dilakukan didapatkan hasil dengan jumlah 14 blok Tanaman Kelapa Sawit Paling Produktifyaitu (BM, BN, BO, BP, BR, $B Y, C E, C F, C K, C Y, C Z, D E$, $D F, D G$ ) dan 26 blok Tanaman Kelapa Sawit tidak produktif yaitu ( $B L, B Q, B S, B W, B X, B Z$, $C A, C B, C C, C D, C G, C L, C M, C N, C O, C P, C Q, C R, C S, C T, C W, C X, D A, D B, D C, D D$ ). Diharapkan perusahaan dapat mengembangkan blok tanaman Kelapa Sawit paling produktif agar kualitas blok tanaman Kelapa Sawit selalu terjaga. Sedangkan untuk blok tanaman Kelapa Sawit tidak produktif perusahaan dapat melakukan perbaikan ulang agar menghasilkan blok tanaman Kelapa Sawit produktif kedepan nya.

Kata kunci : Blok, Kelapa Sawit, Data Mining, K-Means

\section{PENDAHULUAN}


Hamparan luas tanaman perkebunan Kelapa Sawit di Indonesia memiliki luas ribuan hektar, maka dari itu diperlukan identitas suatu sektor area tanaman Kelapa Sawit untuk memudahkan dalam perencanaan, pelaksanaan, pelaporan dan analisa (manajemen perkebunan). Identitas suatu sektor area tanaman Kelapa Sawit itu di sebut dengan Blok. Blok juga merupakan manajemen terkecil dari suatu kebun. Blok juga bermanfaat membentuk Afdeling atau beberapa Afdeling. Untuk memisahkan setiap blok, blok tanaman Kelapa Sawit di perkebunan di batasi oleh jalan. Selain sebagai identitas pada blok, nomor pada blok juga dapat memudahkan perencanaan, pendelegasian, pelaksanaan laporan dan analisa (manajemen kebun). Blok pada tanaman Kelapa Sawit juga mewakili satu tahun tanaman, yaitu penanaman tanaman Kelapa Sawit di selesaikan blok per blok. Begitu juga pada pelaporan produksi, juga di buat blok per blok.

Pada PTP. Nusantara-IV (Persero) khususnya pada Kebun Marjandi yang terletak di Panombean Panei, Kabupaten Simalungun adalah badan usaha milik negara Indonesia yang bergerak pada bidang perkebunan, salah satunya adalah Kelapa Sawit. Di antara banyak blok-blok Tanaman Kelapa Sawit, ada blok-blok tanaman Kelapa Sawit yang produktif dalam menghasilkan Kelapa Sawit dan blokblok tanaman Kelapa Sawit yang tidak produktif. Dan akan berpengaruh pada keuntungan Kebun Marjandi dalam produksi Kelapa Sawit. Namun akan sulit mengetahui bagi perkebunan blok tanaman Kelapa Sawit mana yang kurang produktif dalam menghasilkan Kelapa Sawit. Penelitian terdahulu hanya membahas mengenai unsur-unsur produktifitas dari Kelapa Sawit itu sendiri, bukan produktifitas dari per blok. Seperti penelitian yang di lakukan oleh [1] yang berjudul "Tanggapan Produktivitas Kelapa Sawit (Elaeis guineensis Jacq) "Terhadap Variasi Iklim". Penelitian tersebut menarik kesimpulan bahwa, curah hujan menjadi faktor pembatas produktifitas tanaman Kelapa Sawit sebesar 20\%. Produktifitas yang menurun di sebabkan oleh kondisi drainese yang kurang baik. Kesesuaian iklim juga menunjukkan pengaruh terhadap produktifitas tanaman Kelapa Sawit. Sehingga dapat di simpulkan, bahwa setiap wilayah memiliki karakteristik iklim yang berbeda. Berdasarkan permasalahan yang telah di uraikan di atas, penulis berinisiatif untuk melakukan penelitian dalam menentukan blokblok tanaman Kelapa Sawit yang produktif dengan menggunakan metode Data Mining algoritma K-Means Clustering. Penelitian ini diharapkan dapat membantu perusahaan mengetahui blok mana saja yang paling produktif pada Afdeling III tahun tanam 2005.

\section{METODOLOGI PENELITIAN}

\subsection{Data Mining}

Data mining adalah proses yang menggunakan teknik statistik, matematika, kecerdasan buatan, dan machine learning untuk mengekstraksi dan mengidentifikasi informasi yang bermanfaat dan pengetahuan yang terkait dari database yang besar [2]. 


\subsection{Clustering}

Clustering atau klasifikasi adalah metode yang digunakan untuk membagi rangkaian data menjadi beberapa group berdasarkan kesamaan-kesamaan yang telah ditentukan sebelumnya [3].

\subsection{K-Means}

K-Means merupakan saalah satu metode data clustering non hierarki yang berusaha mempartisi data yang ada ke dalam bentuk satu atau lebih cluster atau kelompok sehingga data yang memiliki karakteristik yang sama dikelompokkan ke dalam satu cluster yang sama dan data yang mempunyai karakteristik yang berbeda dikelompokkan ke dalam kelompok yang lainnya [4]-[10].

\subsection{Kelapa Sawit}

Tanaman kelapa sawit (Elaeis guineensis Jacq) merupakan tumbuhan tropis golongan palma yang termasuk tanaman tahunan. Industri minyak sawit merupakan kontributor penting dalam produksi di Indonesia dan memiliki prospek pengembangan yang cerah[11].

\subsection{Blok Tanaman Kelapa Sawit}

Blok adalah suatu kesatuan areal terkecil dalam administrasi divisi/afdeling, blok juga merupakan manajemen terkecil dari suatu kebun, yang kemudian secara kolektif membentuk afdeling atau divisi, dan beberapa afdeling atau divisi menjadi estate. Pengukuran lahan atau blocking area adalah kegiatan untuk mengetahui luas dan batas lahan yang mengacu pada ketentuan teknis pengukuran tanah untuk mendapatkan detail planimetris $(\mathrm{X}, \mathrm{Y})$ dan tinggi $(\mathrm{h})$ yang dapat memenuhi persyaratan Geometrisnya [1]

\section{HASIL DAN PEMBAHASAN}

Dalam melakukan Clustering, data yang diperoleh akan dihitung terlebih dahulu berdasarkan jumlah blok tanaman Kelapa Sawit tahun tanam Kelapa Sawit 2005 dan 2006, Afdeling III pada PTP. Nusantara-IV (Persero) Kebun Marjandi.. Data tersebut kemudian diakumulasikan berdasarkan 1 kriteria yaitu jumlah blok tanaman Kelapa Sawit seperti yang ditunjukkan pada tabel 1 berikut:

Tabel 1. Data tanaman Kelapa Sawit Berdasarkan Nama Blok

\begin{tabular}{|c|c|c|c|c|c|c|c|c|c|c|c|c|}
\hline \multirow{4}{*}{$\begin{array}{l}\text { NAMA } \\
\text { BLOK }\end{array}$} & \multicolumn{5}{|c|}{ T B S (KG) } & \multirow{4}{*}{$\begin{array}{l}\text { RATA- } \\
\text { RATA }\end{array}$} & \multicolumn{5}{|c|}{$\begin{array}{l}\text { Produksi Per Ha (Kg) } \\
\end{array}$} & \multirow{4}{*}{$\begin{array}{l}\text { RATA- } \\
\text { RATA }\end{array}$} \\
\hline & \multicolumn{2}{|c|}{ REALISASI } & \multicolumn{3}{|c|}{ RKAP } & & \multicolumn{2}{|c|}{ REALISASI } & \multicolumn{3}{|c|}{ RKAP } & \\
\hline & \multirow{2}{*}{$\begin{array}{c}\text { Bulan } \\
\text { ini }\end{array}$} & \multirow{2}{*}{$\begin{array}{c}\text { s/d } \\
\text { Bulan } \\
\text { ini }\end{array}$} & \multirow{2}{*}{$\begin{array}{c}\text { Bulan } \\
\text { ini }\end{array}$} & \multirow{2}{*}{$\begin{array}{c}\text { s/d } \\
\begin{array}{c}\text { Bulan } \\
\text { ini }\end{array}\end{array}$} & \multirow{2}{*}{$\begin{array}{c}\text { setahun } \\
\text { (Ton) }\end{array}$} & & \multirow{2}{*}{$\begin{array}{c}\text { Bulan } \\
\text { ini }\end{array}$} & \multirow{2}{*}{$\begin{array}{c}\text { s/d } \\
\text { Bulan } \\
\text { ini }\end{array}$} & \multirow{2}{*}{$\begin{array}{c}\text { Bulan } \\
\text { ini }\end{array}$} & s/d & setahun & \\
\hline & & & & & & & & & & $\begin{array}{c}\text { Bulan } \\
\text { ini }\end{array}$ & (Ton) & \\
\hline $\mathrm{BL}$ & 20.527 & 20.527 & 23.247 & 23.247 & 394 & $17.588,40$ & 1.283 & 1.283 & 1.453 & 1.453 & 24,61 & $1.099,32$ \\
\hline $\mathrm{BM}$ & 21.408 & 21.408 & 25.339 & 25.339 & 429 & $18.784,60$ & 1.259 & 1.259 & 1.491 & 1.491 & 25,25 & $1.105,05$ \\
\hline $\mathrm{BN}$ & 31.591 & 31.591 & 26.304 & 26.304 & 446 & $23.247,20$ & 1.504 & 1.504 & 1.253 & 1.253 & 21,22 & $1.107,04$ \\
\hline BO & 36.158 & 36.158 & 34.673 & 34.673 & 587 & $28.449,80$ & 1.572 & 1.572 & 1.508 & 1.508 & 25,54 & $1.237,11$ \\
\hline $\mathrm{BP}$ & 24.657 & 24.657 & 33.399 & 33.399 & 566 & $23.335,60$ & 1.072 & 1.072 & 1.452 & 1.452 & 24,60 & $1.014,52$ \\
\hline BQ & 21.156 & 21.156 & 22.508 & 22.508 & 381 & $17.541,80$ & 1.764 & 1.764 & 1.876 & 1.876 & 31,78 & $1.462,36$ \\
\hline $\mathrm{BR}$ & 24.512 & 24.512 & 28.859 & 28.859 & 489 & $21.446,20$ & 1.532 & 1.532 & 1.804 & 1.804 & 30,56 & $1.340,51$ \\
\hline $\mathrm{BS}$ & 23.606 & 23.606 & 18.714 & 18.714 & 317 & $16.991,40$ & 1.967 & 1.967 & 1.560 & 1.560 & 26,42 & $1.416,08$ \\
\hline BW & 17.738 & 17.738 & 16.055 & 16.055 & 272 & $13.571,60$ & 1,613 & 1,613 & 1.460 & 1.460 & 24,73 & 589,59 \\
\hline $\mathrm{BX}$ & 21.357 & 21.357 & 15.601 & 15.601 & 264 & $14.836,00$ & 1.424 & 1.424 & 1.040 & 1.040 & 17,62 & 989,12 \\
\hline BY & 22.191 & 22.191 & 23.130 & 23.130 & 392 & $18.206,80$ & 1.585 & 1.585 & 1.652 & 1.652 & 27,99 & $1.300,40$ \\
\hline $\mathrm{BZ}$ & 24.338 & 24.338 & 19.292 & 19.292 & 327 & $17.517,40$ & 1.521 & 1.521 & 1.206 & 1.206 & 20,43 & $1.094,89$ \\
\hline $\mathrm{CA}$ & 19.983 & 19.983 & 19.942 & 19.942 & 338 & $16.037,60$ & 1.249 & 1.249 & 1.246 & 1.246 & 21,11 & $1.002,22$ \\
\hline
\end{tabular}




\begin{tabular}{|c|c|c|c|c|c|c|c|c|c|c|c|c|}
\hline \multirow{4}{*}{$\begin{array}{l}\text { NAMA } \\
\text { BLOK }\end{array}$} & \multicolumn{5}{|c|}{ T B S (KG) } & \multirow{4}{*}{$\begin{array}{l}\text { RATA- } \\
\text { RATA }\end{array}$} & \multicolumn{5}{|c|}{ Produksi Per Ha (Kg) } & \multirow{4}{*}{$\begin{array}{l}\text { RATA- } \\
\text { RATA }\end{array}$} \\
\hline & \multicolumn{2}{|c|}{ REALISASI } & \multicolumn{3}{|c|}{ RKAP } & & \multicolumn{2}{|c|}{ REALISASI } & \multicolumn{3}{|c|}{ RKAP } & \\
\hline & \multirow{2}{*}{$\begin{array}{c}\text { Bulan } \\
\text { ini }\end{array}$} & \multirow{2}{*}{$\begin{array}{c}\text { s/d } \\
\begin{array}{c}\text { Bulan } \\
\text { ini }\end{array} \\
\end{array}$} & \multirow{2}{*}{$\begin{array}{c}\text { Bulan } \\
\text { ini }\end{array}$} & \multirow{2}{*}{$\begin{array}{c}\text { s/d } \\
\begin{array}{c}\text { Bulan } \\
\text { ini }\end{array} \\
\end{array}$} & \multirow{2}{*}{$\begin{array}{c}\text { setahun } \\
\text { (Ton) }\end{array}$} & & \multirow{2}{*}{$\begin{array}{c}\text { Bulan } \\
\text { ini }\end{array}$} & \multirow{2}{*}{$\begin{array}{c}\text { s/d } \\
\begin{array}{c}\text { Bulan } \\
\text { ini }\end{array} \\
\end{array}$} & \multirow{2}{*}{$\begin{array}{c}\text { Bulan } \\
\text { ini }\end{array}$} & \multirow{2}{*}{$\begin{array}{c}\text { s/d } \\
\begin{array}{c}\text { Bulan } \\
\text { ini }\end{array}\end{array}$} & \multirow{2}{*}{$\begin{array}{c}\text { setahun } \\
\text { (Ton) }\end{array}$} & \\
\hline & & & & & & & & & & & & \\
\hline $\mathrm{CB}$ & 14.907 & 14.907 & 19.011 & 19.011 & 322 & $13.631,60$ & 932 & 932 & 1.188 & 1.188 & 20,13 & 852,03 \\
\hline $\mathrm{CC}$ & 22.096 & 22.096 & 21.319 & 21.319 & 361 & $17.438,20$ & 1.381 & 1.381 & 1.332 & 1.332 & 22,57 & $1.089,71$ \\
\hline $\mathrm{CD}$ & 16.941 & 16.941 & 21.866 & 21.866 & 370 & $15.596,80$ & 1.210 & 1.210 & 1.562 & 1.562 & 26,46 & $1.114,09$ \\
\hline $\mathrm{CE}$ & 26.462 & 26.462 & 21.793 & 21.793 & 369 & $19.375,80$ & 1.654 & 1.654 & 1.362 & 1.362 & 23,07 & $1.211,01$ \\
\hline $\mathrm{CF}$ & 25.210 & 25.210 & 23.636 & 23.636 & 400 & $19.618,40$ & 1.576 & 1.576 & 1.477 & 1.477 & 25,03 & $1.226,21$ \\
\hline CG & 20.360 & 20.360 & 21.441 & 21.441 & 363 & $16.793,00$ & 1.697 & 1.697 & 1.787 & 1.787 & 30,27 & $1.399,65$ \\
\hline CK & 27.826 & 27.826 & 21.226 & 21.226 & 360 & $19.692,80$ & 1.637 & 1.637 & 1.249 & 1.249 & 21,15 & $1.158,63$ \\
\hline CL & 17.735 & 17.735 & 13.993 & 13.993 & 237 & $12.738,60$ & 1.108 & 1.108 & 875 & 875 & 14,82 & 796,16 \\
\hline $\mathrm{CM}$ & 10.827 & 10.827 & 7.683 & 7.683 & 130 & $7.430,00$ & 1.203 & 1.203 & 854 & 854 & 14,46 & 825,69 \\
\hline $\mathrm{CN}$ & 21.661 & 21.661 & 19.397 & 19.397 & 329 & $16.489,00$ & 1.666 & 1.666 & 1.492 & 1.492 & 25,28 & $1.268,26$ \\
\hline $\mathrm{CO}$ & 8.654 & 8.654 & 7.547 & 7.547 & 128 & $6.506,00$ & 1.731 & 1.731 & 1.509 & 1.509 & 25,57 & $1.301,11$ \\
\hline $\mathrm{CP}$ & 10.211 & 10.211 & 10.459 & 10.459 & 177 & $8.303,40$ & 1.276 & 1.276 & 1.307 & 1.307 & 22,15 & $1.037,63$ \\
\hline CQ & 15.011 & 15.011 & 17.542 & 17.542 & 297 & $13.080,60$ & 1.155 & 1.155 & 1.349 & 1.349 & 22,86 & $1.006,17$ \\
\hline CR & 16.517 & 16.517 & 18.469 & 18.469 & 313 & $14.057,00$ & 1.180 & 1.180 & 1.319 & 1.319 & 22,35 & $1.004,07$ \\
\hline $\mathrm{CS}$ & 20.139 & 20.139 & 23.489 & 23.489 & 398 & $17.530,80$ & 1.259 & 1.259 & 1.468 & 1.468 & 24,87 & $1.095,77$ \\
\hline CT & 5.952 & 5.952 & 7.769 & 7.769 & 132 & $5.514,80$ & 1.190 & 1.190 & 1.554 & 1.554 & 26,32 & $1.102,86$ \\
\hline CW & 21.326 & 21.326 & 16.706 & 16.706 & 283 & $15.269,40$ & 1.185 & 1.185 & 928 & 928 & 15,72 & 848,34 \\
\hline $\mathrm{CX}$ & 17.004 & 17.004 & 12.754 & 12.754 & 216 & $11.946,40$ & 1.215 & 1.215 & 911 & 911 & 15,43 & 853,49 \\
\hline $\mathrm{CY}$ & 40.727 & 40.727 & 37.825 & 37.825 & 641 & $31.549,00$ & 1.771 & 1.771 & 1.645 & 1.645 & 27,86 & $1.371,97$ \\
\hline $\mathrm{CZ}$ & 27.073 & 27.073 & 22.405 & 22.405 & 380 & $19.867,20$ & 1.805 & 1.805 & 1.494 & 1.494 & 25,30 & $1.324,66$ \\
\hline DA & 15.818 & 15.818 & 15.678 & 15.678 & 266 & $12.651,60$ & 1.758 & 1.758 & 1.742 & 1.742 & 29,51 & $1.405,90$ \\
\hline DB & 16.603 & 16.603 & 14.909 & 14.909 & 253 & $12.655,40$ & 1.660 & 1.660 & 1.491 & 1.491 & 25,26 & $1.265,45$ \\
\hline DC & 17.203 & 17.203 & 17.052 & 17.052 & 289 & $13.759,80$ & 1.720 & 1.720 & 1.705 & 1.705 & 28,89 & $1.375,78$ \\
\hline DD & 10.471 & 10.471 & 9.662 & 9.662 & 164 & $8.086,00$ & 1.163 & 1.163 & 1.074 & 1.074 & 18,19 & 898,44 \\
\hline $\mathrm{DE}$ & 40.326 & 40.326 & 37.740 & 37.740 & 639 & $31.354,20$ & 2.016 & 2.016 & 1.887 & 1.887 & 31,97 & $1.567,59$ \\
\hline DF & 26.019 & 26.019 & 22.781 & 22.781 & 386 & $19.597,20$ & 1.301 & 1.301 & 1.139 & 1.139 & 19,30 & 979,86 \\
\hline DG & 34.582 & 34.582 & 26.694 & 26.694 & 452 & $24.600,80$ & 1.921 & 1.921 & 1.483 & 1.483 & 25,12 & $1.366,62$ \\
\hline
\end{tabular}

\begin{tabular}{|c|c|c|c|c|c|c|c|c|c|c|c|}
\hline \multirow{4}{*}{$\begin{array}{l}\text { NAMA } \\
\text { BLOK }\end{array}$} & \multicolumn{6}{|c|}{$\begin{array}{r}\text { JUMLAH TANDAN } \\
\end{array}$} & \multirow{4}{*}{$\begin{array}{l}\text { RATA- } \\
\text { RATA }\end{array}$} & \multicolumn{3}{|c|}{ BR,TANDAN(Kg/Ton) } & \multirow{4}{*}{$\begin{array}{c}\text { RATA- } \\
\text { RATA }\end{array}$} \\
\hline & & \multicolumn{2}{|c|}{ REALISASI } & \multicolumn{3}{|c|}{ RKAP } & & \multicolumn{2}{|c|}{ REALISASI } & \multirow[t]{3}{*}{ RKAP } & \\
\hline & \multirow{2}{*}{$\begin{array}{c}\text { Bulan } \\
\text { ini }\end{array}$} & S/D & Sln ini & Bulan & S/D & In ini & & \multirow{2}{*}{$\begin{array}{c}\text { Bulan } \\
\text { ini }\end{array}$} & \multirow{2}{*}{$\begin{array}{c}\text { S/D } \\
\text { Bln } \\
\text { ini }\end{array}$} & & \\
\hline & & Jumlah & Per/PKK & ini & Jumlah & Per/PKK & & & & & \\
\hline $\mathrm{BL}$ & 1.014 & 1.014 & 0,67 & 1.196 & 1.196 & 0,79 & 736,91 & 20,24 & 20,24 & 19,44 & 19,97 \\
\hline $\mathrm{BM}$ & 1.060 & 1.060 & 0,56 & 1.254 & 1.254 & 0,67 & 771,54 & 20,20 & 20,20 & 20,21 & 20,20 \\
\hline $\mathrm{BN}$ & 1.566 & 1.566 & 0,68 & 1.359 & 1.359 & 0,59 & 975,21 & 20,17 & 20,17 & 19,35 & 19,90 \\
\hline $\mathrm{BO}$ & 1.805 & 1.805 & 0,68 & 1.774 & 1.774 & 0,67 & $1.193,23$ & 20,03 & 20,03 & 19,55 & 19,87 \\
\hline $\mathrm{BP}$ & 1.221 & 1.221 & 0,49 & 1.731 & 1.731 & 0,70 & 984,20 & 20,19 & 20,19 & 19,29 & 19,89 \\
\hline $\mathrm{BQ}$ & 1.041 & 1.041 & 0,75 & 1.156 & 1.156 & 0,84 & 732,60 & 20,33 & 20,33 & 19,47 & 20,04 \\
\hline $\mathrm{BR}$ & 1.246 & 1.246 & 0,71 & 1.490 & 1.490 & 0,85 & 912,26 & 19,67 & 19,67 & 19,37 & 19,57 \\
\hline BS & 1.174 & 1.174 & 0,90 & 943 & 943 & 0,72 & 705,94 & 20,11 & 20,11 & 19,84 & 20,02 \\
\hline BW & 905 & 905 & 0,76 & 898 & 898 & 0,76 & 601,25 & 19,60 & 19,60 & 17,88 & 19,03 \\
\hline $\mathrm{BX}$ & 1.094 & 1.094 & 0,68 & 868 & 868 & 0,54 & 654,20 & 19,52 & 19,52 & 17,98 & 19,01 \\
\hline BY & 1.135 & 1.135 & 0,64 & 1.290 & 1.290 & 0,73 & 808,56 & 19,55 & 19,55 & 17,92 & 19,01 \\
\hline $\mathrm{BZ}$ & 1.242 & 1.242 & 0,74 & 1.056 & 1.056 & 0,63 & 766,23 & 19,60 & 19,60 & 18,27 & 19,16 \\
\hline CA & 1.003 & 1.003 & 0,63 & 1.003 & 1.003 & 0,63 & 668,88 & 19,92 & 19,92 & 19,88 & 19,91 \\
\hline CB & 757 & 757 & 0,46 & 969 & 969 & 0,58 & 575,51 & 19,69 & 19,69 & 19,62 & 19,67 \\
\hline $\mathrm{CC}$ & 1.123 & 1.123 & 0,70 & 1.102 & 1.102 & 0,69 & 741,90 & 19,68 & 19,68 & 19,35 & 19,57 \\
\hline CD & 861 & 861 & 0,55 & 1.107 & 1.107 & 0,71 & 656,21 & 19,68 & 19,68 & 19,75 & 19,70 \\
\hline $\mathrm{CE}$ & 1.342 & 1.342 & 0,78 & 1.098 & 1.098 & 0,64 & 813,57 & 19,72 & 19,72 & 19,85 & 19,76 \\
\hline $\mathrm{CF}$ & 1.288 & 1.288 & 0,76 & 1.193 & 1.193 & 0,71 & 827,25 & 19,57 & 19,57 & 19,81 & 19,65 \\
\hline CG & 1.046 & 1.046 & 0,87 & 1.098 & 1.098 & 0,91 & 714,96 & 19,46 & 19,46 & 19,53 & 19,48 \\
\hline CK & 1.416 & 1.416 & 0,64 & 1.176 & 1.176 & 0,53 & 864,20 & 19,65 & 19,65 & 18,05 & 19,12 \\
\hline CL & 897 & 897 & 0,57 & 787 & 787 & 0,50 & 561,51 & 19,77 & 19,77 & 17,78 & 19,11 \\
\hline $\mathrm{CM}$ & 553 & 553 & 0,69 & 426 & 426 & 0,53 & 326,54 & 19,58 & 19,58 & 18,05 & 19,07 \\
\hline $\mathrm{CN}$ & 1.094 & 1.094 & 0,82 & 988 & 988 & 0,74 & 694,26 & 19,80 & 19,80 & 19,63 & 19,74 \\
\hline $\mathrm{CO}$ & 440 & 440 & 0,89 & 380 & 380 & 0,77 & 273,61 & 19,67 & 19,67 & 19,85 & 19,73 \\
\hline $\mathrm{CP}$ & 514 & 514 & 0,63 & 522 & 522 & 0,64 & 345,55 & 19,87 & 19,87 & 20,02 & 19,92 \\
\hline CQ & 757 & 757 & 0,58 & 905 & 905 & 0,69 & 554,21 & 19,83 & 19,83 & 19,39 & 19,68 \\
\hline CR & 827 & 827 & 0,55 & 934 & 934 & 0,62 & 587,20 & 19,97 & 19,97 & 19,77 & 19,90 \\
\hline $\mathrm{CS}$ & 1.020 & 1.020 & 0,63 & 1.158 & 1.158 & 0,71 & 726,22 & 19,74 & 19,74 & 20,28 & 19,92 \\
\hline $\mathrm{CT}$ & 303 & 303 & 0,58 & 392 & 392 & 0,75 & 231,89 & 19,64 & 19,64 & 19,83 & 19,70 \\
\hline CW & 1.091 & 1.091 & 0,58 & 927 & 927 & 0,50 & 672,85 & 19,55 & 19,55 & 18,02 & 19,04 \\
\hline CX & 872 & 872 & 0,59 & 716 & 716 & 0,48 & 529,51 & 19,50 & 19,50 & 17,82 & 18,94 \\
\hline
\end{tabular}




\begin{tabular}{|c|c|c|c|c|c|c|c|c|c|c|c|}
\hline \multirow{4}{*}{$\begin{array}{l}\text { NAMA } \\
\text { BLOK }\end{array}$} & \multicolumn{6}{|c|}{ JUMLAH TANDAN } & \multirow{4}{*}{$\begin{array}{l}\text { RATA- } \\
\text { RATA }\end{array}$} & \multicolumn{3}{|c|}{ BR,TANDAN(Kg/Ton) } & \multirow{4}{*}{$\begin{array}{l}\text { RATA- } \\
\text { RATA }\end{array}$} \\
\hline & & \multicolumn{2}{|c|}{ REALISASI } & \multicolumn{3}{|c|}{ RKAP } & & \multicolumn{2}{|c|}{ REALISASI } & \multirow[t]{3}{*}{ RKAP } & \\
\hline & \multirow{2}{*}{$\begin{array}{c}\text { Bulan } \\
\text { ini }\end{array}$} & S/D & $\ln$ ini & Bulan & S/D & $\ln$ ini & & \multirow{2}{*}{$\begin{array}{c}\text { Bulan } \\
\text { ini }\end{array}$} & \multirow{2}{*}{$\begin{array}{c}\text { S/D } \\
\text { Bln } \\
\text { ini }\end{array}$} & & \\
\hline & & Jumlah & Per/PKK & ini & Jumlah & Per/PKK & & & & & \\
\hline $\mathrm{CY}$ & 2.062 & 2.062 & 0,72 & 1.916 & 1.916 & 0,67 & $1.326,23$ & 19,75 & 19,75 & 19,74 & 19,75 \\
\hline $\mathrm{CZ}$ & 1.346 & 1.346 & 0,83 & 1.150 & 1.150 & 0,71 & 832,26 & 20,11 & 20,11 & 19,49 & 19,90 \\
\hline DA & 804 & 804 & 0,88 & 796 & 796 & 0,87 & 533,63 & 19,67 & 19,67 & 19,68 & 19,67 \\
\hline DB & 850 & 850 & 0,73 & 758 & 758 & 0,65 & 536,23 & 19,53 & 19,53 & 19,66 & 19,57 \\
\hline DC & 877 & 877 & 0,80 & 872 & 872 & 0,79 & 583,27 & 19,62 & 19,62 & 19,55 & 19,60 \\
\hline DD & 534 & 534 & 0,59 & 515 & 515 & 0,57 & 349,86 & 19,61 & 19,61 & 18,77 & 19,33 \\
\hline $\mathrm{DE}$ & 2.040 & 2.040 & 0,92 & 1.939 & 1.939 & 0,87 & $1.326,63$ & 19,77 & 19,77 & 19,47 & 19,67 \\
\hline $\mathrm{DF}$ & 1.319 & 1.319 & 0,64 & 1.149 & 1.149 & 0,56 & 822,87 & 19,73 & 19,73 & 19,83 & 19,76 \\
\hline DG & 1.758 & 1.758 & 0,90 & 1.356 & 1.356 & 0,70 & $1.038,27$ & 19,67 & 19,67 & 19,68 & 19,67 \\
\hline
\end{tabular}

\subsection{Centroid Data}

Penentuan titik cluster ini dilakukan dengan mengambil nilai terbesar (maksimum) untuk cluster tanaman Kelapa Sawit dengan blok paling produktif (C1) dan nilai terkecil (minimum) untuk cluster blok tidak produktif (C2). Nilai titik tersebut dapat diketahui pada Tabel 2 berikut:

Tabel 2. Centroid Data Awal

\begin{tabular}{|l|l|l|l|l|}
\hline CLUSTER & W & $\mathbf{X}$ & $\mathbf{y}$ & $\mathbf{z}$ \\
\hline MAX & 31549,00 & 1567,59 & 1326,63 & 20,20 \\
\hline MIN & 5514,80 & 589,59 & 231,89 & 18,94 \\
\hline
\end{tabular}

\subsection{Clustering Data}

Setelah data nilai pusat claster awal ditentukan, maka langkah selanjutnya adalah menghitung jarak masing-masing data terhadap pusat cluster dengan menggunakan rumus yang perhitungannya dapat kita lihat sebagai berikut:

$$
\begin{aligned}
& D(1.1)=\sqrt{\begin{array}{c}
(31549,00-17588,40)^{2}+(1567,59-1099,322)^{2} \\
+\left(1326,63-736,91^{2}\right)+(20,20-19,97)^{2}
\end{array}} \\
& =13980,89 \\
& D(1.2)=\sqrt{\begin{array}{c}
(31549,00-18784,60)^{2}+(1567,59-1105,05)^{2} \\
+\left(1326,63-771,54^{2}\right)+(20,20-20,20)^{2}
\end{array}} \\
& \quad=12784,83
\end{aligned}
$$

Dan seterusnya sampai dengan $\mathrm{D}(1.40)$

Perhitungan jarak terhadap centroid cluster kedua, seperti berikut:

$$
\begin{aligned}
& \mathrm{D}(2.1)=\sqrt{\begin{array}{c}
(5514,80-17588,40)^{2}+(589,59-1099,322)^{2} \\
+\left(231,89-736,91^{2}\right)+(18,94-19,97)^{2}
\end{array}} \\
& =12094,89
\end{aligned}
$$


Dari data blok tanaman Kelapa Sawit tahun tanam Kelapa Sawit 2005 dan 2006, Afdeling III pada PTP. Nusantara-IV (Persero) Kebun Marjandi didapatkan pengelompokan pada iterasi 1 untuk 2 cluster tersebut. Cluster blok paling produktif (C1) yakni 13 blok, dan cluster blok tidak produktif (C2) yakni 27 blok. Proses pencarian jarak terpendek, pengelompokan data pada iterasi 1 dan Clustering data dapat digambarkan pada tabel dan gambar berikut:

Tabel 3. Perhitungan Jarak Pusat Cluster

\begin{tabular}{|c|c|c|c|c|c|c|c|}
\hline $\begin{array}{l}\text { Nama } \\
\text { BLOK }\end{array}$ & W & $\mathbf{X}$ & $\mathbf{Y}$ & $\mathbf{Z}$ & C1 & C2 & $\begin{array}{c}\text { Iterasi } 1 \\
\text { Jarak } \\
\text { Terpendek }\end{array}$ \\
\hline $\mathrm{BL}$ & 17588,40 & 1099,32 & 736,91 & 19,97 & 14078,45 & 12098,67 & 12098,67 \\
\hline BM & 18784,60 & 1105,05 & 771,54 & 20,20 & 12890,77 & 13293,25 & 12890,77 \\
\hline $\mathrm{BN}$ & 23247,20 & 1107,04 & 975,21 & 19,90 & 8478,11 & 17753,28 & 8478,11 \\
\hline BO & 28449,80 & 1237,11 & 1193,23 & 19,87 & 3499,98 & 22959,15 & \\
\hline BP & 23335,60 & 1014,52 & 984,20 & 19,89 & 8396,52 & 17839,33 & \\
\hline $\mathrm{BQ}$ & 17541,80 & 1462,36 & 732,60 & 20,04 & 14117,54 & 12072,92 & 12072,92 \\
\hline BR & 21446,20 & 1340,51 & 912,26 & 19,57 & 10244,22 & 15962,53 & 244,22 \\
\hline BS & 16991,40 & 1416,08 & 705,94 & 20,02 & 14665,75 & 11521,00 & 521,00 \\
\hline BW & 13571,60 & 589,59 & 601,25 & 19,03 & 18096,28 & 8076,99 & 8076,99 \\
\hline BX & 14836,00 & 989,12 & 654,20 & 19,01 & 16819,38 & 9347,41 & 9347,41 \\
\hline BY & 18206,80 & 1300,40 & 808,56 & 19,01 & 5,85 & 12726,57 & 6,57 \\
\hline $\mathrm{BZ}$ & & 109 & 766,23 & 19,16 &, 41 & 8,06 & \\
\hline $\mathrm{CA}$ & & 1002,22 & 668,88 & 19,91 & 54 & &, 58 \\
\hline $\mathrm{CB}$ & 1363 & 852,03 & 575,51 & 19,67 & 180 & 03 & \\
\hline $\mathrm{CC}$ & 174 & 1089,71 & 741,90 & 19,57 & 7,48 & 8,46 &, 46 \\
\hline CD & 155 & 1114,09 & 656,21 & 19,70 & 9,42 & 10111,93 & 1,93 \\
\hline $\mathrm{CE}$ & 19375,80 & 1211,01 & 813,57 & 19,76 & 12299,52 & 8,43 & 9,52 \\
\hline $\mathrm{CF}$ & 19618,40 & 1226,21 & 827,25 & 19,65 & 12058,19 & 14131,46 & 58,19 \\
\hline CG & 16793,00 & 1399,65 & 714,96 & 19,48 & 14862,41 & 11322,31 & 22,31 \\
\hline CK & 19692,80 & 1158,63 & 864,20 & 19,12 & 11984,54 & 14203,53 & 34,54 \\
\hline CL & & 796,16 & 561,51 & 19,11 & 6,56 & 29 & \\
\hline $\mathrm{CM}$ & & & 326 & 19,07 & 242 & & \\
\hline $\mathrm{CN}$ & 1648 & 1268,26 & 694,26 & 19,74 & 151 &, 42 &, 42 \\
\hline $\mathrm{CO}$ & 6506 & 1301,11 & 273,61 & 19,73 & 251 & 3,23 & 23 \\
\hline $\mathrm{CP}$ & 40 & 1037,63 & 345,55 & 19,92 & 5,11 & 891,56 & 1,56 \\
\hline $\mathrm{CQ}$ & & 1006,17 & 554,21 & 19,68 & 18569,33 & 7598,74 & 8,74 \\
\hline CR & 14057,00 & 1004,07 & 587,20 & 19,90 & 17596,71 & 8571,20 & 8571,20 \\
\hline CS & 17530,80 & 1095,77 & 726,22 & 19,92 & 14136,33 & 12040,92 & 12040,92 \\
\hline CT & 5514,80 & 1102,86 & 231,89 & 19,70 & 26118,49 & 846,27 & 846,27 \\
\hline CW & 15269,40 & 848,34 & 672,85 & 19,04 & 16393,33 & 9775,05 & 9775,05 \\
\hline $\mathrm{CX}$ & & & 529,51 & 18,94 & 1970 & & \\
\hline $\mathrm{CY}$ & & $1371, \mathrm{c}$ & 1326,23 & 19,75 & 1578,72 & 2606 & 8,72 \\
\hline $\mathrm{CZ}$ & 19867 & & 832,26 & 19,90 & 1180 & 14384,55 & 11809,30 \\
\hline DA & 12651 & 1405,90 & 533,63 & 19,67 & 18989,55 & 7206,12 & 7206,12 \\
\hline DB & 12655,40 & 1265,45 & 536,23 & 19,57 & 18987,35 & 7195,33 & 7195,33 \\
\hline $\mathrm{DC}$ & 13759,80 & 1375,78 & 583,27 & 19,60 & 17884,56 & 8301,99 & 8301,99 \\
\hline DD & 8086,00 & 898,44 & 349,86 & 19,33 & 23555,04 & 2662,54 & 2662,54 \\
\hline $\mathrm{DE}$ & 31354,20 & 1567,59 & 1326,63 & 19,67 & 1578,63 & 25874,68 & 1578,63 \\
\hline $\mathrm{DF}$ & 19597,20 & 979,86 & 822,87 & 19,76 & 12088,89 & 14101,26 & 12088,89 \\
\hline DG & 24600,80 & 1366,62 & 1038,27 & 19,67 & 7141,02 & 19115,58 & 7141,02 \\
\hline
\end{tabular}


Tabel 4. Pengelompokkan Data Iterasi 1

\begin{tabular}{|c|c|c|}
\hline Nama & C1 & C2 \\
BLOK & & \\
\hline BL & & 1 \\
\hline BM & 1 & \\
\hline BN & 1 & \\
\hline B0 & 1 & \\
\hline BP & 1 & \\
\hline BQ & & 1 \\
\hline BR & 1 & \\
\hline BS & & 1 \\
\hline BW & & 1 \\
\hline BX & & 1 \\
\hline BY & & 1 \\
\hline BZ & & 1 \\
\hline CA & & 1 \\
\hline CB & & 1 \\
\hline CC & & 1 \\
\hline CD & & 1 \\
\hline CE & 1 & \\
\hline CF & 1 & \\
\hline CG & & 1 \\
\hline CK & 1 & \\
\hline CL & & 1 \\
\hline CM & & 1 \\
\hline CN & & 1 \\
\hline CO & & 1 \\
\hline CP & & 1 \\
\hline CQ & & 1 \\
\hline CR & & 1 \\
\hline CS & & 1 \\
\hline CT & & 1 \\
\hline CW & & 1 \\
\hline CX & & 1 \\
\hline CY & 1 & \\
\hline CZ & 1 & \\
\hline DA & & 1 \\
\hline DB & & 1 \\
\hline DD & & 1 \\
\hline DE & 1 & 1 \\
\hline C & \\
\hline C & \\
\hline
\end{tabular}

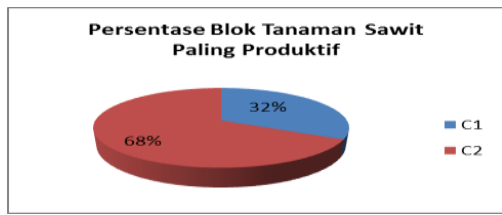

Gambar 1. Clustering Data 
Proses K-Means akan terus beriterasi sampai pengelompokan data sama dengan pengelompokan data iterasi sebelumnya. Proses iterasi tersebut berhenti pada iterasi ke 4, pada iterasi 4 akan dilakukan proses mencari nilai titik tengah atau centroid yang dapat diketahui pada Tabel 5 berikut:

Tabel 5. Data Centroid Iterasi 4

\begin{tabular}{|l|c|c|c|c|}
\hline CLUSTER & W & $\mathbf{x}$ & $\mathbf{y}$ & $\mathbf{z}$ \\
\hline MAX & 22794,69 & 1236,51 & 964,02 & 19,69 \\
\hline MIN & 13598,56 & 1084,39 & 579,27 & 19,56 \\
\hline
\end{tabular}

Setelah mendapatkan nilai titik tengah atau centroid, proses sama dilakukan dengan mencari jarak terdekat. Proses pencarian jarak terpendek, pengelompokan data pada iterasi 3 dan Clustering data dapat digambarkan pada tabel dan gambar berikut:

Tabel 6. Perhitungan Jarak Pusat Cluster Iterasi 4

\begin{tabular}{|c|c|c|c|c|c|c|c|}
\hline $\begin{array}{l}\text { Nama } \\
\text { BLOK }\end{array}$ & $\mathbf{W}$ & $\mathbf{X}$ & $\mathbf{Y}$ & $\mathbf{Z}$ & C1 & $\mathrm{C} 2$ & $\begin{array}{c}\text { Iterasi } 4 \\
\text { Jarak } \\
\text { Terpendek }\end{array}$ \\
\hline $\mathrm{BL}$ & 17588,40 & 1099,32 & 736,91 & 19,97 & 5213,04 & 3992,98 & 3992,98 \\
\hline $\mathrm{BM}$ & 18784,60 & 1105,05 & 771,54 & 20,20 & 4016,85 & 5189,64 & 4016,85 \\
\hline $\mathrm{BN}$ & 23247,20 & 1107,04 & 975,21 & 19,90 & 470,80 & 9656,79 & 470,80 \\
\hline $\mathrm{BO}$ & 28449,80 & 1237,11 & 1193,23 & 19,87 & 5659,76 & 14864,71 & 5659,76 \\
\hline $\mathrm{BP}$ & 23335,60 & 1014,52 & 984,20 & 19,89 & 585,04 & 9745,71 & 585,04 \\
\hline $\mathrm{BQ}$ & 17541,80 & 1462,36 & 732,60 & 20,04 & 5262,83 & 3964,28 & 3964,28 \\
\hline $\mathrm{BR}$ & 21446,20 & 1340,51 & 912,26 & 19,57 & 1353,48 & 7858,87 & 1353,48 \\
\hline $\mathrm{BS}$ & 16991,40 & 1416,08 & 705,94 & 20,02 & 5811,80 & 3411,37 & 3411,37 \\
\hline BW & 13571,60 & 589,59 & 601,25 & 19,03 & 9252,86 & 496,02 & 496,02 \\
\hline $\mathrm{BX}$ & 14836,00 & 989,12 & 654,20 & 19,01 & 7968,55 & 1243,36 & 1243,36 \\
\hline $\mathrm{BY}$ & 18206,80 & 1300,40 & 808,56 & 19,01 & 4590,96 & 4618,99 & 4590,96 \\
\hline $\mathrm{BZ}$ & 17517,40 & 1094,89 & 766,23 & 19,16 & 5282,89 & 3923,31 & 3923,31 \\
\hline $\mathrm{CA}$ & 16037,60 & 1002,22 & 668,88 & 19,91 & 6767,59 & 2442,07 & 2442,07 \\
\hline $\mathrm{CB}$ & 13631,60 & 852,03 & 575,51 & 19,67 & 9179,37 & 234,73 & 234,73 \\
\hline $\mathrm{CC}$ & 17438,20 & 1089,71 & 741,90 & 19,57 & 5363,10 & 3843,08 & 3843,08 \\
\hline $\mathrm{CD}$ & 15596,80 & 1114,09 & 656,21 & 19,70 & 7205,50 & 1999,94 & 1999,94 \\
\hline $\mathrm{CE}$ & 19375,80 & 1211,01 & 813,57 & 19,76 & 3422,29 & 5783,37 & 3422,29 \\
\hline $\mathrm{CF}$ & 19618,40 & 1226,21 & 827,25 & 19,65 & 3179,25 & 6026,61 & 3179,25 \\
\hline $\mathrm{CG}$ & 16793,00 & 1399,65 & 714,96 & 19,48 & 6009,07 & 3212,82 & 3212,82 \\
\hline CK & 19692,80 & 1158,63 & 864,20 & 19,12 & 3104,47 & 6101,35 & 3104,47 \\
\hline CL & 12738,60 & 796,16 & 561,51 & 19,11 & 10073,77 & 907,15 & 907,15 \\
\hline $\mathrm{CM}$ & 7430,00 & 825,69 & 326,54 & 19,07 & 15383,39 & 6179,15 & 6179,15 \\
\hline $\mathrm{CN}$ & 16489,00 & 1268,26 & 694,26 & 19,74 & 6311,53 & 2898,56 & 2898,56 \\
\hline $\mathrm{CO}$ & 6506,00 & 1301,11 & 273,61 & 19,73 & 16303,44 & 7102,45 & 7102,45 \\
\hline $\mathrm{CP}$ & 8303,40 & 1037,63 & 345,55 & 19,92 & 14505,84 & 5300,52 & 5300,52 \\
\hline CQ & 13080,60 & 1006,17 & 554,21 & 19,68 & 9725,45 & 524,43 & 524,43 \\
\hline $\mathrm{CR}$ & 14057,00 & 1004,07 & 587,20 & 19,90 & 8748,90 & 465,49 & 465,49 \\
\hline $\mathrm{CS}$ & 17530,80 & 1095,77 & 726,22 & 19,92 & 5271,13 & 3935,00 & 3935,00 \\
\hline $\mathrm{CT}$ & 5514,80 & 1102,86 & 231,89 & 19,70 & 17295,90 & 8091,24 & 8091,24 \\
\hline $\mathrm{CW}$ & 15269,40 & 848,34 & 672,85 & 19,04 & 7540,91 & 1690,02 & 1690,02 \\
\hline $\mathrm{CX}$ & 11946,40 & 853,49 & 529,51 & 18,94 & 10863,74 & 1668,96 & 1668,96 \\
\hline CY & 31549,00 & 1371,97 & 1326,23 & 19,75 & 8762,85 & 17968,27 & 8762,85 \\
\hline
\end{tabular}




\begin{tabular}{|c|c|c|c|c|c|c|c|}
\hline $\begin{array}{c}\text { Nama } \\
\text { BLOK }\end{array}$ & $\mathbf{W}$ & $\mathbf{X}$ & $\mathbf{Y}$ & $\mathbf{Z}$ & $\mathbf{C 1}$ & $\mathbf{C 2}$ & \begin{tabular}{c} 
Iterasi 4 \\
\cline { 4 - 8 }
\end{tabular} \\
& & & & & & & $\begin{array}{c}\text { Jarak } \\
\text { Terpendek }\end{array}$ \\
\hline CZ & 19867,20 & 1324,66 & 832,26 & 19,90 & 2931,77 & 6278,34 & 2931,77 \\
\hline DA & 12651,60 & 1405,90 & 533,63 & 19,67 & 10153,63 & 1001,09 & 1001,09 \\
\hline DB & 12655,40 & 1265,45 & 536,23 & 19,57 & 10148,35 & 961,35 & 961,35 \\
\hline DC & 13759,80 & 1375,78 & 583,27 & 19,60 & 9043,98 & 333,05 & 333,05 \\
\hline DD & 8086,00 & 898,44 & 349,86 & 19,33 & 14725,38 & 5520,47 & 5520,47 \\
\hline DE & 31354,20 & 1567,59 & 1326,63 & 19,67 & 8573,59 & 17777,93 & 8573,59 \\
\hline DF & 19597,20 & 979,86 & 822,87 & 19,76 & 3210,87 & 6004,49 & 3210,87 \\
\hline DG & 24600,80 & 1366,62 & 1038,27 & 19,67 & 1812,32 & 11015,42 & 1812,32 \\
\hline
\end{tabular}

Tabel 7. Pengelompokkan Data Iterasi 4

\begin{tabular}{|c|c|c|}
\hline Nama & C1 & C2 \\
\hline BL & & 1 \\
\hline BM & 1 & \\
\hline BN & 1 & \\
\hline BO & 1 & \\
\hline BP & 1 & \\
\hline BQ & & 1 \\
\hline BR & 1 & \\
\hline BS & & 1 \\
\hline BW & & 1 \\
\hline BX & & 1 \\
\hline BY & 1 & \\
\hline BZ & & 1 \\
\hline CA & & 1 \\
\hline CB & & 1 \\
\hline CC & & 1 \\
\hline CD & & 1 \\
\hline CE & 1 & \\
\hline CF & 1 & \\
\hline CG & & 1 \\
\hline CK & 1 & \\
\hline CL & & 1 \\
\hline CM & & 1 \\
\hline CN & & 1 \\
\hline CO & & 1 \\
\hline CP & & 1 \\
\hline CQ & & 1 \\
\hline CR & & 1 \\
\hline CS & & 1 \\
\hline CT & & 1 \\
\hline CW & & 1 \\
\hline CX & & 1 \\
\hline CY & 1 & \\
\hline CZ & 1 & \\
\hline DA & & 1 \\
\hline DB & & 1 \\
\hline DC & & 1 \\
\hline DD & & 1 \\
\hline DE & 1 & \\
\hline & \\
\hline
\end{tabular}




\begin{tabular}{|c|c|c|}
\hline Nama & C1 & C2 \\
\hline DF & 1 & \\
\hline DG & 1 & \\
\hline
\end{tabular}

C1 $: 14$, C2: 26

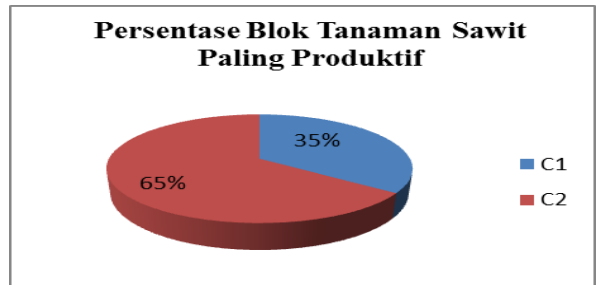

Gambar 2. Clustering Data Iterasi 4

\subsection{Analisis Data}

Pada iterasi 4, pengelompokan data yang dilakukan terhadap 2 cluster dengan iterasi 3 didapatkan hasil yang sama. Dari 40 data berdasarkan jumlah blok tanaman Kelapa Sawit tahun tanam Kelapa Sawit 2005 dan 2006, Afdeling III pada PTP. Nusantara-IV (Persero) Kebun Marjandi dapat dikertahui, 14 blok Tanaman Kelapa Sawit Paling Produktif yaitu dan 26 blok Tanaman Kelapa Sawit tidak produktif.

\subsection{Hasil Clustering Dengan Rapidminner}

Pada tahap pengujian algoritma ini untuk membuktikan kebenaran pada tahap analisa sebelumnya dan pengujian secara manual, maka perlu dilakukan pengujian lagi untuk pengelompokan data meningkatkan mutu pembelajaran menggunakan algoritma $K$-Means dapat dilihat pada gambar berikut :

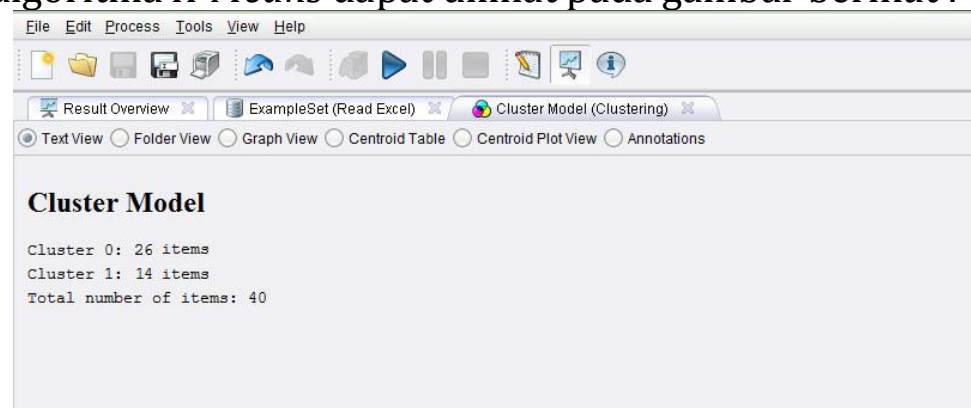

Gambar 3. Data Hasil Clustering

\section{KESIMPULAN}

Dengan demikian dari hasil penelitian, pembahasan dan pengujian model dapat disimpulkan bahwa :

a. Pada iterasi 4, pengelompokan data yang dilakukan terhadap 2 cluster dengan iterasi 3 didapatkan hasil yang sama. Dari 40 data berdasarkan jumlah blok tanaman Kelapa Sawit tahun tanam Kelapa Sawit 2005 dan 2006, Afdeling III pada PTP. Nusantara-IV (Persero) Kebun Marjandi dapat dikertahui, 14 blok Tanaman Kelapa Sawit Paling Produktif yaitu (BM, BN, BO, BP, BR, BY, CE, CF, CK, CY, CZ, DE, DF, DG) dan 26 blok Tanaman Kelapa Sawit Tidak Produktif yaitu 
( BL, BQ, BS, BW, BX, BZ, CA, CB, CC, CD, CG, CL, CM, CN, CO, CP, CQ, CR, CS, CT, CW, CX, DA, DB, DC, DD).

b. Penelitian tentang penerapan data mining untuk pengelompokkan blok tanaman Kelapa Sawit dengan algoritma clustering K-Means dilakukan menggunakan bantuan aplikasi pengolah angka Microsoft Excel dan aplikasi Rapidminer untuk uji data yang telah diolah.

c. Penerapan algoritma clustering K-Means dapat diterapkan pada data blok tanaman Kelapa Sawit dengan tujuan untuk pengelompokkan blok tanaman Kelapa Sawit

\section{DAFTAR PUSTAKA}

[1] E. Tarwaca and S. Putra, "Tanggapan Produktivitas Kelapa Sawit ( Elaeis guineensis Jacq . ) terhadap Variasi Iklim The Productivities Responses of Oil Palms (Elaeis guineensis Jacq .) to Variation of Climate Elements," vol. 4, no. 4, pp. 21-34, 2015.

[2] R. Setiawan and N. Tes, "PENERAPAN DATA MINING MENGGUNAKAN ALGORITMA KMEANS CLUSTERING UNTUK MENENTUKAN STRATEGI PROMOSI MAHASISWA BARU ( Studi Kasus : Politeknik LP3I Jakarta )," vol. 3, no. 1, pp. 76-92, 2016.

[3] B. M. Metisen and H. L. Sari, "ANALISIS CLUSTERING MENGGUNAKAN METODE K-MEANS DALAM PENGELOMPOKKAN PENJUALAN PRODUK PADA SWALAYAN FADHILA," vol. 11, no. 2, pp. 110-118, 2015.

[4] I. Parlina, A. P. Windarto, A. Wanto, and M. R. Lubis, "Memanfaatkan Algoritma K-Means dalam Menentukan Pegawai yang Layak Mengikuti Asessment Center untuk Clustering Program SDP," CESS (Journal of Computer Engineering System and Science), vol. 3, no. 1, pp. 87-93, 2018.

[5] M. G. Sadewo, A. P. Windarto, and D. Hartama, "Penerapan Datamining Pada Populasi Daging Ayam Ras Pedaging Di Indonesia Berdasarkan Provinsi Menggunakan K-Means," InfoTekJar (Jurnal Nasional Informatika dan Teknologi Jaringan), vol. 2, no. 1, pp. 60-67, 2017.

[6] M. G. Sadewo, A. P. Windarto, and A. Wanto, "Penerapan Algoritma Clustering dalam Mengelompokkan Banyaknya Desa/Kelurahan Menurut Upaya Antisipasi/ Mitigasi Bencana Alam Menurut Provinsi dengan K-Means," KOMIK (Konferensi Nasional Teknologi Informasi dan Komputer), vol. 2, no. 1, pp. 311-319, 2018.

[7] R. W. Sari, A. Wanto, and A. P. Windarto, "Implementasi Rapidminer dengan Metode KMeans (Study Kasus: Imunisasi Campak pada Balita Berdasarkan Provinsi)," KOMIK (Konferensi Nasional Teknologi Informasi dan Komputer), vol. 2, no. 1, pp. 224-230, 2018.

[8] S. Sudirman, A. P. Windarto, and A. Wanto, "Data Mining Tools | RapidMiner: K-Means Method on Clustering of Rice Crops by Province as Efforts to Stabilize Food Crops In Indonesia," IOP Conference Series: Materials Science and Engineering, vol. 420, no. 12089, pp. 1-8, 2018.

[9] A. P. Windarto, "Implementation of Data Mining on Rice Imports by Major Country of Origin Using Algorithm Using K-Means Clustering Method," International Journal of artificial intelligence research, vol. 1, no. 2, pp. 26-33, 2017.

[10] A. P. Windarto, "Penerapan Data Mining Pada Ekspor Buah-Buahan Menurut Negara Tujuan Menggunakan K-Means Clustering," Techno.COM, vol. 16, no. 4, pp. 348-357, 2017.

[11] N. Sirait, "IMPLEMENTASI K-MEANS CLUSTERING PADA PENGELOMPOKAN MUTU BIJI SAWIT ( Studi Kasus : PT . Multimas Nabati Asahan ),” vol. 16, pp. 368-372, 2017. 